\title{
Health Belief Theory of Knowledge Model and Drinking Behavior by Providing Education in Tubercolusis Patients in the Work Area of the Batang-Batang Health Center
}

\author{
Fathorrahman', \\ Ratna Wardani ${ }^{2}$ \\ ${ }^{1}$ Sumenep District Health Center \\ Batang-Batang \\ ${ }^{2}$ Indonesia Strada Institute of \\ Health Sciences \\ Email: \\ makmang02@gmail.com
}

Received: October $4^{\text {nd }} 2021$

Accepted : October $15^{\text {rd }} 2021$

Published : November $27^{\text {th }} 2021$

\begin{abstract}
\end{abstract}
Tuberculosis is a disease caused by the bacterium Mycobacterium Tuberculosis where a third of the world's population is estimated to have been infected by the disease and has become the center of world attention with many control efforts that have been carried out, incidents that have attracted the attention of health workers in the form of death, although the death rate has decreased, new TB cases continue to increase this is caused by the lack of education and undisciplined behavior by tuberculosis sufferers. The purpose of this study is knowledge and behavior of taking medication before health education, knowledge and behavior of taking medication after health education and analyzing the effect of health education on the application of the Health Belief Model theory on knowledge and behavior of taking medication in tuberculosis patients in the working area of the Batang-Batang Health Center. This research is a quantitative preexperimental approach with a cross sectional survey design on 100 tuberculosis patients at the Batang-Batang Health Center, Sumenep Regency, the sample was taken using a simple random sampling method. Data collection uses a data collection format, a parametric test type questionnaire with interval data type using a Likert scale with a range of 1 , then the data is analyzed using paired $\mathrm{T}$ test and linear regression test. The results showed that almost all respondents had knowledge before being given sufficient education category as many as 85 respondents $(85 \%)$ and almost all respondents had behavior before being given sufficient education category as many as 86 respondents $(86 \%)$, almost all respondents had knowledge after being given education at good category as many as 97 respondents (97\%) and almost all respondents have behavior after being given education in the good category as many as 99 respondents (99\%) and there is a relationship between Health Belief Theory on knowledge and drug-taking behavior in tuberculosis patients in the working area of Batang-Batang Public Health Center.

Conclusion: There is a relationship between Health Belief Theory on knowledge and behavior of taking medication for tuberculosis patients in the working area of Batang-Batang Public Health Center. With the patient's knowledge that is still lacking, it can be improved by providing adequate information/education, especially about tuberculosis related causes, signs and symptoms, treatment and prevention including how to take the right medicine.

Keywords: Pulmonary tuberculosis, health belief model, education 


\section{INTRODUCTION}

Health Development is an effort carried out by all components of the nation which aims to increase awareness, willingness and ability to live a healthy life for everyone so that the highest level of public health can be realized. (Wijaya, 2014). Public health center which is a health service facility that organizes public health efforts and first-level individual health efforts by prioritizing promotive and preventive efforts to achieve the highest public health status in its working area. (Permenkes No. 43 of 2019 concerning public health centers).

Tuberculosis is a disease caused by the bacterium Mycobacterium Tuberculosis where a third of the world's population is estimated to have been infected by the disease and has become the center of world attention with many control efforts that have been carried out, incidents that have attracted the attention of health workers in the form of death, although mortality has decreased but new TB cases continue to increase this is caused by a lack of education and undisciplined behavior by tuberculosis sufferers (Iksan, 2020).

Based on a preliminary study conducted on December 5, 2020 at the Sumenep district health center by interviewing 121 families of tuberculosis patients, it was found that 121 family members said they did not know in detail the function of family health care, only knew that pulmonary tuberculosis was contagious and had to take them for treatment. While the other two people said they knew most of the functions of family care and how to care for family members suffering from pulmonary tuberculosis

Based on the case that the researchers described above, the researcher wants to conduct research on the Health Belief Model theory on knowledge and behavior of taking medication by providing education to tuberculosis patients in the Batang-Batang Health Center work area

\section{MATERIALS AND METHODS}

In this study, the researcher used a quantitative design with a pre-experimental approach with a cross sectional approach, namely a research design that collects data at one time to the sample (Creswell, 2014). This study will analyze the effectiveness of the Health Belief theory of knowledge and behavior of taking medication by providing education to tuberculosis patients at the Batang-Batang Health Center, Sumenep Regency. The total population is 120 respondents and a sample of 100 respondents is taken using simple random sampling technique. Data analysis used paired $\mathrm{T}$ test and Linear Regression test. This research has passed the ethical test number: 2282/KEPK/II/2021

\section{RESULTS}

Table 1 Paired T-Test Health Belief theory Model knowledge and behavior of taking medication by providing education to tuberculosis sufferers at the Batang-Batang Health Center, Sumenep Regency which was held on 1-30 March 2021 with a total of 100 respondents

\begin{tabular}{|c|c|c|c|}
\hline Normality Test & Df & Sign & Description \\
\hline $\begin{array}{l}\text {-Knowledge } \\
\text { Before and after } \\
\text { Education } \\
\text {-Behavior } \\
\text { Before and after } \\
\text { Education }\end{array}$ & $\begin{array}{l}100 \\
100\end{array}$ & 0,01 & $\begin{array}{l}(<0.05) \text { data } \\
\text { distribution is not } \\
\text { normal } \\
(<\quad 0.05) \text { data } \\
\text { distribution is not } \\
\text { normal }\end{array}$ \\
\hline
\end{tabular}


rom the results of the normality test, the data is not normally distributed. Furthermore, using Wilcoxon analysis

Table 2 Uji Wilcoxon Teori Health Belief Model pengetahuan dan perilaku minum obat dengan memberikan edukasi pada penderita tuberkulosis di Puskesmas BatangBatang Kabupaten Sumenep Regency which was held on 1-30 March 2021 with a total of 100 respondents

\begin{tabular}{|l|l|l|}
\hline Variable & $p$-value & Description \\
\hline $\begin{array}{l}\text {-Knowledge Before and } \\
\text { after Education } \\
\text {-Behavior and after } \\
\begin{array}{l}\text { Before and } \\
\text { Education }\end{array}\end{array}$ & 0,000 & $\begin{array}{l}<0.05 \text { data distribution is } \\
\text { normal } \\
<0.05 \text { data distribution is } \\
\text { normal }\end{array}$ \\
\hline
\end{tabular}

Based on the output from the Wilcoxon statistical test, it is known that Asymp.Sig (2.tailled). value of 0.000 is smaller than 0.05 , it can be concluded that the hypothesis is accepted, meaning that there is a difference in knowledge and behavior between before and after being given education to respondents with tuberculosis in the working area of the Batang-Batang Table 3. Linear Regression Test with the basic assumption test

\begin{tabular}{|l|l|l|l|}
\hline Variable & $\begin{array}{l}\text { Asymp.Sig value. } \\
\text { (2-tailed) }\end{array}$ & $\begin{array}{l}\text { Significance } \\
\text { Level }\end{array}$ & Description \\
\hline $\begin{array}{l}\text { Knowledge and Behavior } \\
\text { before and after being given } \\
\text { education }\end{array}$ & 0,057 & 0,05 & Normal \\
\hline
\end{tabular}

Based on the results of the Linear Regression Test from the Basic Assumption Test, the normality test is Knowledge and Behavior before and after being given Asymp.Sig (2.tailled) education. value of 0.057 is smaller than 0.05 , it can be concluded that the hypothesis is accepted, meaning that there is a difference in knowledge between before and after being given education to respondents with tuberculosis in the working area of the Batang-Batang Public Health Center.

Table 4. Linear Regression Test with Multicollinearity Test

Referring to the calculation results of the Tolerance and VIF values, it can be concluded that

\begin{tabular}{|c|c|c|c|c|c|c|c|c|}
\hline \multirow{2}{*}{\multicolumn{2}{|c|}{ Model }} & \multicolumn{2}{|c|}{$\begin{array}{l}\text { Unstandardized } \\
\text { Coefficients }\end{array}$} & \multirow{2}{*}{$\begin{array}{l}\text { Standardized } \\
\text { Coefficients } \\
\text { Beta } \\
\end{array}$} & \multirow[b]{2}{*}{$\mathrm{t}$} & \multirow[b]{2}{*}{ Sig. } & \multicolumn{2}{|c|}{ Collinearity Statistics } \\
\hline & & $B$ & Std. Error & & & & Tolerance & VIF \\
\hline 1 & $\begin{array}{l}\text { (Constant) } \\
\text { Difference } \\
\text { between } \\
\text { Knowledge and } \\
\text { behavior }\end{array}$ & $\begin{array}{l}9.892 \\
-.026\end{array}$ & $\begin{array}{l}.565 \\
.226\end{array}$ & -.011 & $\begin{array}{l}17.520 \\
-.113\end{array}$ & $\begin{array}{l}.000 \\
.910\end{array}$ & 1.000 & 1.000 \\
\hline
\end{tabular}


there is no multicollinearity between the independent variables in the regression model Table 5. Linear Regression Test with Heteroscedasticity Test

\begin{tabular}{|l|l|l|l|}
\hline Variable & $\begin{array}{l}\text { Asymp.Sig } \\
\text { value. (2-tailed) }\end{array}$ & $\begin{array}{l}\text { Significance } \\
\text { Level }\end{array}$ & Description \\
\hline $\begin{array}{l}\text { Knowledge and Behavior } \\
\text { before and after being } \\
\text { given education }\end{array}$ & 0,173 & 0,05 & There is no heteroscedasticity \\
\hline
\end{tabular}

based on the results of the Heteroscedasticity Test. The difference in knowledge scores with the Asymp.Sig value. (2-tailled) 0.173 is more than 0.05 , it can be concluded that there is no heteroscedasticity

\section{DISCUSSION}

A. Knowledge and Behavior of Taking Medicines Before Health Education for Tuberculosis Patients

The results showed that most of the respondents had sufficient knowledge before being given ecudation, as many as 85 respondents $(85 \%)$. While a small proportion of respondents had good knowledge before being given education, namely 15 respondents $(15 \%)$.

According to the tabulation, it was explained that most of the respondents' behavior before health education was sufficient, namely as many as 86 respondents $(86 \%)$ and a small portion of the behavior showed good, namely 14 respondents (14\%)

According to Notoatmojo (2010) knowledge is the result of knowing and this occurs after people have sensed a certain object. Sensing occurs through the five human senses, namely the senses of sight, hearing, smell, taste and touch. Knowledge (cognitive) is a very important domain in the formation of a behavior

According to the researcher, the knowledge of tuberculosis patients who is less will be one of the factors in the formation of new behaviors, namely in terms of adherence to taking tuberculosis drugs. The patient's knowledge is the first step in assessing an object or stimulus he receives, because with knowledge the patient will have the will to make changes and take action related to the stimulus he receives, in this case adherence to taking tuberculosis drug B. Knowledge and Behavior of Taking Drugs after being educated on Tuberculosis Patients The results showed that after education almost all respondents had good knowledge, namely 97 respondents (97\%), and only a small part had sufficient knowledge, namely 3 respondents (3\%). While the results of tabulation of drug taking behavior after being given education showed that almost all respondents showed good behavior, namely as many as 99 respondents (99\%) and only a small portion showed adequate behavior, namely 1 respondent $(1 \%)$.

According to Notoatmodjo (2010) explains that behavior change is part of health education or health counseling as a support for other health programs. The formation of behavioral changes, one of which is due to the interaction between individuals and the environment through a process called the learning process

According to researchers, the health belief model is a very effective way of shaping health behavior change. Because through this method we as health workers can help sufferers understand and identify the things that are the cause of why it is difficult for sufferers to prevent and cure disease in this case about how patients take tuberculosis drugs correctly.

C. Analysis of the Effect of Health Education on the Application of Health Belief Model Theory on Knowledge and Behavior of Taking Drugs in Tuberculosis Patients 
Based on the results of the Linear Regression Test consisting of the Basic Assumption Test, the normality test of Knowledge and Behavior before and after being given Asymp.Sig (2.tailled) education. value of 0.057 is smaller than 0.05 , it can be concluded that the hypothesis is accepted, meaning that there is a difference in knowledge between before and after being given education to respondents with tuberculosis in the working area of the Batang-Batang Health Center, in the Multicollinearity Test the results of the Tolerance value there are independent variables that have a value Tolerance is more than 0.10 with the Tolerance value of each independent variable being 1.0. Meanwhile, the results of the calculation of the Variance Inflation Factor (VIF) value also show the same thing, namely the VIF value of the variable has a value greater than 0.10 , referring to the calculation results of the Tolerance and VIF values, it can be concluded that there is no multicollinearity between the independent variables in the regression model. Heteroscedasticity Test results The difference between knowledge scores and the Asymp.Sig value. (2-tailled) 0.173 is more than 0.05 , it can be concluded that there is no heteroscedasticity

\section{CONCLUSION}

Almost all respondents have knowledge before being given education to patients with tuberculosis in the sufficient category as many as 85 respondents $(85 \%)$ and almost all respondents have behavior before being given education to patients with tuberculosis in the sufficient category as many as 86 respondents (86\%), Almost all of the respondents have knowledge after being given education to Tuberculosis Patients in good category as many as 97 respondents (97\%) and almost all respondents have behavior after being given education to Tuberculosis Patients in good category as many as 99 respondents (99\%), There is a relationship between the Health Belief Theory on knowledge and behavior of taking medication for tuberculosis patients in the working area of the Batang-Batang Public Health Center

\section{SUGGESTION}

For Respondents It is hoped that the knowledge of patients who are still lacking can be improved by providing adequate information/education, especially about tuberculosis related to its causes, signs and symptoms, treatment and prevention including how to take medication correctly. For Educational Agencies It is hoped that educational institutions can use the results of this study as learning input and can be developed again for further research to be more useful for readers and researchers. For Researcher It is hoped that further researchers can add research areas for much better and diverse results and collaborate across programs and across sectors to monitor and supervise adherence in taking tuberculosis drugs. For Puskesmas It is hoped that the Puskesmas can use the results of this study as learning input for all employees of the Batang-Batang Health Center, Sumenep

ACKNOWLEDGMENT

I solemnly declare that to the best of my knowledge, in this thesis there is no scientific work that has been submitted by another person to obtain an academic degree at a university, and no work or opinion has been written or published by another person., except those quoted in this manuscript and mentioned in the citation sources and bibliography.

CONFLICT OF INTEREST

In this study, there is no interest whatsoever concerning myself or with other institutions other than the Indonesian Strada Institute of Health Sciences, Kediri City. 


\section{REFERENCES}

Ikhsan, et al. 2020. FAMILY FUNCTIONS WITH THE DOTS PROGRAM TUBERCULOSIS TREATMENT RESULTS. Pelni Jakarta Nursing Academy, University of Indonesia, University of Muhammadiyah Jakarta. Silampari Journal of Nursing Volume 3, Number 2, June 2020 e-ISSN: 2581-1975 p-ISSN: 2597-7482 DOI: https://doi.org/10.31539/jks .$v 3 i 2.1118$.

Juliati, et al. 2020. Analysis of Factors Affecting Compliance Behavior Prevention and Compliance with Taking Drugs in Pulmonary Tuberculosis Patients Based on the Toeir Health Belief Model. Faculty of Nursing. Airlangga University. Surabaya. Vol. 5, No. 2

Ministry of Health RI.2016. Tuberculosis Management. Jakarta.

Yulisyaningrum, et al. 2010. RELATIONSHIP OF CONTACT HISTORY OF PULMONARY TUBERCULOSIS (TB) WITH THE EVENT OF CHILD LUNG TB IN THE PULMONARY DISEASE TREATMENT CENTER (BP4) PURWOKERTO ISSN : 1978-0575. Yogyakarta. Faculty of Public Health, Ahmad Dahlan University. Vol. 4, No. 1

Indonesian Ministry of Health. 2015. Data and Information Center of the Ministry of Health of the Republic of Indonesia Tuberculosis Finds Treat Until Healed. Jakarta. Pusdatin.

Kowalak. 2011. Textbook of Pathophysiology. Jakarta: EGC

Manampiring, et al.2020. Anti-Mycobacterium Test of Hibiscus Flower Extract (Hibiscus rosa sinensis L.) as an Anti-Tuberculosis Medicinal Plant. Manado.pISSN 2085-9481 eISSN 2597999X Biomedical Journal. 2020;12(1):48-53 National Accredited: Decree of the Director General of Research and Development Strengthening DOI: https://doi.org/10.35790/jbm.12.1.2020.27006 Kemenristekdikti RI No. 28/E/KPT/2019

Yuda Arditia Alif. 2018. The relationship between characteristics, knowledge, attitudes and actions of pulmonary tuberculosis patients with medication adherence at the Tanah Kali Kewall Public Health Center. Surabaya. Airlangga University Library.

Patricia Bilqis Nevada, et al. 2019. The Effect of Health Belief Model (Hbm) Education on Patients with Pulmonary Tuberculosis on Knowledge and Perception of Treatment Compliance. Health Polytechnic of the Ministry of Health Surabaya. Surabaya. ISSN: 2684-9518

Empirical Studies in Public Accounting Firms. Indonesian Accounting Research Journal. Vol. 5, No. 3. Page 341- 364

Reni, et al. (2014). Performance Appraisal The right system to assess employee performance and improve company competitiveness, second edition. Jakarta: King GrafindoPersada.

Rivai, Veithzal and Sagala, Ella Jauvani. (2014). Human Resource Management for Companies from Theory to Practice. Jakarta: The King of GrafindoPersada

Sasa Ike Kusdyah. (2016). Human Resource Management. Yogyakarta:Andi Publisher,

Timpe and Gearge (2012). Increasing Employee Productivity Job Satisfaction, And Organizational Commitment. Hospital And Health Services Ad. Vol. 41 No. 2. Pages 160- 175.

Widodo Susilo Toto, et al. (2016). Analysis of the Effect of Leadership Style on Job Satisfaction, Organizational Commitment and Employee Performance (Empirical Study at the Ministry of Religion of Kendal Regency and the Ministry of Religion of Semarang City). Journal of Management \& Organization Studies. Volume 3, Number 2. Pg. 69-81. 